International Journal of Instruction e-ISSN: 1308-1470 • www.e-iji.net
October $2020 \bullet$ Vol.13, No.4

p-ISSN: 1694-609X

pp. $177-196$

Received: 31/08/2019

Revision: 30/03/2020

Accepted: 20/04/2020

OnlineFirst:08/07/2020

\title{
Integrating Reading-to-write Strategies and Pairing Composition and Reading Courses for First-year, At-risk College Students
}

\section{Tara Hembrough}

Assoc. Prof., Southeastern Oklahoma State University, USA, thembrough@se.edu

This study evaluated the effect of employing reading-to-write strategies and joining college composition and reading courses for provisionally admitted, firstyear-writing students in the United States. The article discusses a mixed methods study of an experimental course-design model involving 47 students in the experimental group, 47 students in the control group, and five teachers, which aimed to improve students' reading-to-write strategies. For the curricular initiative, an experimental group of provisionally admitted students studied reading-to-write practices and took Composition I and Reading I as 16-week, linked courses. Meanwhile, the control group also enrolled in Composition I and Reading I courses, but they were unconnected. Both groups were given a pre-test and posttest measuring students' reading levels, as well as their being assessed on a literature review essay they completed for Composition I. Additionally, experimental students were surveyed and instructors were interviewed about students' attitudes toward the reading-to-write practices and linked class design. Concentrating on Composition I, this article portrays the experimental linked courses' framework and its assessment practices, including a measurement of the reading-to-write outcomes for the literature review. Summarily, according to both the quantitative and qualitative data gathered, in cooperation with Reading I instructors, Composition I teachers utilizing reading-to-write approaches presented students with a cohesive, relevant curriculum. They also assisted students in reading, thinking critically, and writing and revising at a higher and sufficiently necessary level, including for the literature review, with all being important firstyear composition outcomes.

Keywords: first-year composition, reading-to-write, reading and writing linked courses, critical thinking, student persistence, writing program administration

\section{INTRODUCTION}

Beginning college students experiencing difficulty in reading or writing academic texts may benefit from interventions and additional support (Thiede, Griffin, Wiley, \& Anderson, 2010; Yang, 2010). As a best practice, writing administrators and writing

Citation: Hembrough, T. (2020). Integrating Reading-to-write Strategies and Pairing Composition and Reading Courses for First-year, At-risk College Students. International Journal of Instruction, 13(4), 177-196. https://doi.org/10.29333/iji.2020.13412a 
faculty creating classes for developmental and first-year students can implement reading-to-write strategies and integrate composition and reading instruction by teaching these disciplines as linked classes (Mutnick \& Lamos, 2014) as these areas are interrelated (Hayes \& Williams, 2016; Hern \& Snell, 2013; Horning \& Kraemer, 2013; Pacello, 2014). For college students, the reading-to-write process involves the acts of reading, summarizing, and critiquing sources from various genres with diverse rhetorical aims and styles; reacting personally to these texts and discussing them; composing work with specified purposes contextualizing what one has read; and reading one's work for the processes of drafting, revising, and editing (Flower, Stein, Ackerman, Kantz, McCormick, \& Peck, 1990; Yu, 2016). In writing classes, teachers can join reading and writing practices in order to aid students in not only reacting narrowly and personally to texts (Helmers, 2003) but also understanding diverse genres and viewing reading as a dialogue between readers and writers. Indeed, reading prefigures and affects students' writing outcomes (Conley, 2005), and when students comprehend their course readings and can discuss them with greater clarity in their writing assignments, they are more motivated to complete both activities and also can work at a higher level (Bunn, 2013).

As a model to facilitate the college transition process of provisionally-admitted, FY students with low reading and writing levels at the study's university, the English and Reading Departments created an experimental set of linked composition and reading courses. An experimental group of provisionally admitted students in the college's Academic Success Program (ASP) enrolled simultaneously in Composition I and Reading I during the same 16-week semester. The program's goal was to raise students' ability to read, summarize, and critique sources from various genres with diverse rhetorical aims and styles; react personally to these texts and discuss them; compose work with specified purposes contextualizing what they read; and read their work for the processes of drafting, revising, and editing. Overall, the paired Composition I and Reading I sections would provide the experimental group with greater instruction in reading-to-write practices that would assist them in addressing their composition class's curriculum. Specifically, with the separate course teachers collaborating, students taking Composition I (three credit hours) and Reading I (one credit hour) in a joined fashion would spend extra time in the latter class covering their Composition I readings. Meanwhile, for the study, a control group of students also enrolled in Composition I and Reading I courses, with Composition I's curriculum remaining the same, but the two classes were unconnected. Both groups were given a pre-test and post-test measuring students' reading levels, as well as students being assessed on the literature review essay they completed for Composition I.

For the study, some adjustments in the experimental composition and reading courses' scheduling and curricula were made. In both courses, teachers utilized the textbooks assigned for Composition I, with the reading instructors fashioning further lessons incorporating various reading-to-write strategies, including active reading. In Reading I, the teachers also focused on covering the shared course reader containing many nonfiction essays and articles, as well as their discussing reading theory and criticalthinking topics. For Composition I, the author formulated a standardized syllabus and schedule with reading and assignment due dates that the writing instructors followed, 
and the reading teachers utilized as a basis also. Thus, instructors from both departments attempted to teach the same readings during a given week, and they also met weekly to converse about the study's progress (see Luebke, 2002).

In Composition I, students engage with multiple academic genres, and the class promotes a process-oriented approach to composition, with students revising most essay drafts and reflecting upon their writing methods. In the course, students write a literacy narrative, advertisement analysis, rhetorical analysis, literature review, and in-class essay as the final exam. Additionally, students compile a portfolio and compose a reflective essay contextualizing their work (see Horning \& Kramer, 2013; Skomski, 2013). Thus, students engage in reading-to-write practices for most units by reading, summarizing, and critiquing sources from genres with diverse rhetorical aims and styles; reacting personally to these texts and discussing them; composing work with specified purposes contextualizing what they read; and reading their work for the processes of drafting, revising, and editing. The largest essay, the literature review, is a commonly assigned genre in FYC (Grabe \& Zhang, 2013), and it calls upon students to demonstrate their reading, critical thinking, and writing practices at the highest level, with students composing eight to ten pages of work.

In implementing reading-to-write strategies through the connected classes, departmental administrators expected that the experimental students could learn to understand and analyze a range of texts more thoroughly and critically, discuss them with greater expertise in their Composition I essays, and apply better reading strategies to their work for drafting and revision purposes. Thus, for the study, the author asked the following research questions: Would an experimental group of provisionally-admitted, Composition I students benefit from focusing on reading-to-write practices and taking joined reading and writing courses in order to hone their reading, critical thinking, and writing skills? Specifically, would the students' writing practices themselves improve as a result of their becoming better readers in multiple ways? If so, how could any growth in students' reading, critical thinking, and writing abilities be measured in their writing?

\section{CONTEXT AND REVIEW OF LITERATURE}

\section{Implementing Reading-to-write Practices and Linking Reading and Composition}

Writing teachers who interrogate their expectations and goals for students will realize that they place various reading-to-write practices at their class's forefront in demonstrating to students what and how to read as part of the writing act (Helmers, 2003). Nevertheless, in composition studies, scholars rarely discuss the importance of reading, and reading studies are conducted mostly in colleges of education. As a further hinderance to integrating the disciplines of reading and writing, at many universities, the classes are taught by separate departments. Additionally, publishers who portray reading as a process in their literature often target primary and secondary school teachers, a scenario causing conversations about teaching reading in college to seem developmental and remedial in nature. In the larger view, writing teachers may believe that their students should know how to read well enough already before beginning college. Likewise, many composition researchers are more concerned with what their students 
are reading than with how and whether they are learning to read well (Helmers, 2003). Whatever the case, in the end, most college writing courses do not address students' reading skills sufficiently in order to assist them (Belet Boyaci \& Güner, 2018), and many beginning university students experience difficulty in reading and thinking critically; utilizing a range of vocabulary; participating in class discussions; defining a research topic; annotating texts; summarizing, evaluating, and integrating sources; modelling rhetorical strategies and genre conventions; creating written responses, arguments, narratives, and reflections; and proofreading (Gruenbaum, 2012; Horning \& Kramer, 2013; Howard, Rodrigue, \& Serviss, 2010; Skomski, 2013).

Since the Dartmouth Conference of 1966, the discipline of writing has changed in focus from teachers showcasing model texts to placing students' language and ideas at the composition class's forefront (Helmers, 2003). Yet, students must learn both to read and write in order to join and formulate communities of practice. Specifically, to gather information and write about it, students must be able to read competently (Rosyida \& Ghufron, 2018), and reading sources before one begins composing should be viewed as an integral part of the writing process (Sharp, 2016). How readers select, analyze, and understand texts is connected to the choices that authors make about a text's goals, genre, style, and audience. Indeed, having students read texts that assist them in investigating their culture locally and more widely allows them to view themselves within the reading's context (Irwansyah, Nurgiyantoro, \& Sugirin. 2019). Likewise, being able to read well is also linked to thinking critically (Zubaidah, Corebima, Mahanal, \& Mistianah, 2018). Thus, overall, as part of most FYC classes' requirements, students must learn to demonstrate their rhetorical consciousness through reading, thinking, and writing acts (Helmers, 2003).

Many college writing teachers need to bolster their students' reading comprehension (Javadi, \& Mohammadi, 2019). Yet, implementing reading-to-write theories in the composition classroom, as well as offering students a linked reading class, can aid students with their reading, thinking, and writing processes, including comprehending and remembering readings, inventing theories based upon them, and critiquing textual ideas (see Cumming, Lai, \& Cho, 2016; Grabe \& Zang, 2013; Horning \& Kramer, 2013; Marsh, 2015; Skomski, 2013). To demonstrate to students that reading and writing processes are interwoven, FYC teachers can employ various reading-to-write practices, including providing students with advanced reading theories, as well as selecting varied genres that students can read, study, respond to, and model (Horning \& Kraemer, 2013). Meanwhile, enrolling in reading classes themselves can produce additional benefits for college writers. In taking a reading course, students can formulate a stronger vocabulary, a tactic assisting them in becoming better writers (Pathan, Ismail, \& Soomro, 2019), such as within a FYC class. Furthermore, students spending greater time reading works about which they will compose possess less writing anxiety (Jawas, 2019). Likewise, reading instruction aids students composing essays in improving their source utilization (Cumming, Lai, \& Cho, 2016). Indeed, many researchers now identify students' writing with integrated sources as being the key component to their demonstrating academic literacy (Hern \& Snell, 2013). Overall, college students may show less interest in learning to write than in learning to read, but reading and writing teachers who 
collaborate can work to combine these skills in their classrooms to students' benefit (Hung \& Van, 2018).

Besides featuring reading-to-write theories in composition classrooms, teachers have provided accounts of linked reading and writing classes involving developmental, English Language Learner, and FYC courses (see Bunn, 2013; Jenkins, Zeidenberg, \& Kienzl, 2009; Kalamkarian, Raufman, \& Edgecombe, 2015; Marsh, 2015; Perin, 2011). In one study with a reading-to-write approach, FYC students, who read, drafted, and received feedback from their teacher and peers, improved multiple compositional practices, including their utilization of grammar and mechanics, vocabulary, and organization, and the analysis of complex texts (Yu, 2016). Nonetheless, this study did not reveal how many students improved their compositional practices or to what degree. Comparably, in another study concerning FYC students practicing reading-to-write strategies, students attributed their general writing gains in the composition class to their related growth in reading skills (Lockhart \& Soliday, 2016). Yet, in this second study, students' specific assessed writing improvements remained unidentified. Third, in a study of linked writing and reading courses, the experimental students performed better than their counterparts, who took the individual, standalone classes, in fulfilling course outcomes for both classes (Goen \& Gillotte-Tropp, 2003). However, this study’s authors did not explain sufficiently how the classes were connected or describe greatly the reading-to-write practices or course assignments that students utilized. Additionally, overall, the first two studies lacked a specified control group, and none featured a large number of participants or employed a mixed method study in order to implement and benefit from a greater number and type of instruments.

Although a few of scholars have described reading-to-write practices and linked FYC and reading classes, none have documented an initiative connecting Composition I and Reading I classes specifically. Therefore, this study was conducted to address this gap. Overarching Composition I objectives involve teaching students to engage with a text's rhetorical situation through reading-to-write practices, as well as to read their work for the drafting process. Consequently, the study's Composition and Reading program directors linked the two courses to provide experimental students with access to the reading-to-write techniques they would need as readers, thinkers, and writers. In implementing reading-to-write strategies within the joined classes, the departmental administrators expected that students could learn to comprehend and analyze a range of texts more thoroughly and critically, discuss them with greater expertise in their Composition I essays, and apply better reading strategies to their work for drafting and revision purposes. Thus, for the study, the author generated the following hypotheses based upon the research questions: The experimental group of provisionally-admitted, Composition I students could benefit from studying reading-to-write premises and taking conjoined reading and writing courses in order to hone their reading, critical thinking, and writing skills. Indeed, students' writing practices themselves might improve as a result of their becoming better readers in multiple ways. Additionally, any improvement in students' reading, critical thinking, and writing abilities might be measured by assessing students' Composition I's literature review paper 


\section{METHOD}

\section{Research Methods and Purpose}

Having Institutional Review Board approval, the author fashioned this study as an exploratory, mixed methods study (Cresswell \& Cresswell, 2017) involving the design of a FY, two-course sequence, since an exploratory, mixed methods study offers a learning opportunity for researchers (Schutt, 2014), and a mixed methods study allows an issue to be contemplated via multiple research phases and multiple method types (Cresswell \& Cresswell, 2017). Overall, a mixed methods study involves utilizing both quantitative and qualitative research methods, as "one data source alone is insufficient, results need to be explained, exploratory results need to be further examined, a study needs to be enhanced through adding a second method, [and] a theoretical stance needs to be advanced through the use of both types of methods" (Cresswell \& Cresswell, 2017, p. 60). Thus, a mixed methods, explanatory design was employed, with the collection of quantitative research followed by qualitative research (Morse \& Neihaus, 2009). The qualitative data was constructed upon the quantitative data, and the two datasets were connected in the study's intermediate stage (Creswell \& Cresswell, 2017). The basis for this approach is that the quantitative data and their succeeding analysis provide a basic understanding of the research problem. Indeed, the qualitative data and their analysis assist in illuminating the quantitative results by viewing participants' ideas in greater depth (Creswell \& Cresswell, 2017; Teddlie \& Tashakkori, 2009). Concerning the study's aims or purpose, the author investigated the effects of incorporating a linked reading course focusing on reading-to-write strategies on an experimental group of students' engagement patterns with Composition I, specifically as assessed in the literature review. Largely, the author hoped to identify whether the group of ASP students taking the connected reading course would be able to hone their reading, critical thinking, and writing skills in order to become stronger writers. Also, the author wished to consider how any improvement in the experimental students' reading, critical thinking, and writing abilities might be measured in their writing.

To gather data, the author utilized instruments, including surveys, inventories, a rubric, student papers, interviews, a report, and field notes. The surveys' closed-ended questions and rubric provided quantitative data (Merriam, 1998), and the surveys' openended questions, papers, interviews (Boyce \& Neale, 2006), report, and field notes (Bernard \& Bernard, 2012) offered qualitative data. For the surveys, the author asked some Likert-style questions, with answers ranging from 1 "strongly disagree" to 5 "strongly agree." Additionally, other questions were open answer allowing for participant commentary (Allen \& Seaman, 2007), including concerning how the linked courses affected the experimental students' outcomes. During the course, both the experimental students and teachers took the pre- and post-surveys depicting students' relationships to their reading, critical thinking, writing, and revision practices and describing how they responded to the initiative and how it influenced their learning methods and outcomes. Next, because writing teachers should give their students a test of their reading comprehension level at the beginning and end of a study as a measurement (Joliffe, 2007), students in both groups underwent testing. The inventories 
utilized to assess students' reading levels were the Metacognitive Reading Strategies Inventory (Mokharti \& Reichard, 2002) and Reading Inventory for the Classroom (Flynnt \& Cooter, 2004). Then, the author created a rubric to measure all students' writing outcomes for the Composition I literature review. On a five-point scale, the rubric indicated an essay's use of organization; development and clarification of ideas; diction, style, and voice; and audience and genre features, all of which the linked courses' reading-to-write strategies might affect. In following, the author utilized both groups of students' end-of-the-semester reflective paper to note themes affiliated with their reactions to the course results. Subsequently, for the interviews, the author employed semi-structured questions to give teachers the opportunity to discuss their ideas on the linked course design, and through the interviews, they were able to elaborate upon their survey answers also (see Boyce \& Neale, 2006). For the interview process, the author interviewed the teachers only. (See the appendix for interview questions.) Finally, concerning the experimental group, the Reading director provided a report of the Reading initiative's side, and the author performed classroom observations and discussed the connected courses' results with the composition and reading teachers, as well as the Reading director, to create field notes for the author's participant observer's role (see Bernard \& Bernard, 2012).

Both the reading inventories and rubric implemented yielded adequate results for the study's usage. For the Metacognitive Reading Strategies Inventory, the resultant relationship was $a=.91$. For the Reading Inventory for the Classroom, the relationship was $a=.71$. Thus, for both measurements, the levels resulting were adequate. Second, the author utilized the rubric to measure students' writing outcomes for the literature review. For this scenario, acting as raters, two colleagues and the author rated and then compared their results for students' literature reviews. In all areas, correlation coefficients used to assess inter-rater reliability within the dataset ranged from good to adequate. Specifically, the inter-rater reliability coefficients are as follows: 1) development and clarity $(.864 \%) ; 2$ ) organization $(.775 \%) ; 3)$ diction, style, and voice $(.775 \%)$; and 4$)$ audience and genre requirements $(.596 \%)$.

To provide for flexibility and adaptation, the study applied a constructivist, groundedtheory methodology to collect data and formulate themes in the data linked to the research questions as an analysis technique (Strauss, 1987). In filing data, the author gave participants pseudonyms and kept the list of pseudonyms and associated names in a password-encrypted file. Having gathered the study data, the author assessed it. Through a coding process, the author analyzed the data relevant to the study's setting, participants, and chronology (Cresswell \& Cresswell, 2017) and, based upon the study's research questions, considered emergent themes linked to students' reading, thinking, and writing practices. Subsequently, relying on the existing literature, and the themes determined during the study, the author utilized an analytical framework to connect the data and build a storyline (Yin, 2009) outlining the study's details (Cresswell \& Cresswell, 2017) as connected to the author's general research question concerning whether experimental students would benefit from enrolling in a Reading I class focused on reading-to-write strategies complementing their Composition I course. To offer credibility to the study's claims, the author was immersed in prolonged field engagement 
(Bernard \& Bernard, 2012) and contemplated the research questions over a long period (Cresswell \& Miller, 2000). Furthermore, the author utilized the process of data triangulation by implementing "multiple sources of data" and "multiple methods to confirm the [study's] emerging findings" (Merriam, 1985, p. 204). By selecting an exploratory, mixed methods study; utilizing surveys, inventories, a rubric, and artifacts, including student papers; and employing a constructivist grounded theory, the author followed the protocols of other researchers reviewed to ensure that the research design was appropriate and the methodology consistent with the practice.

\section{Sample Demographics}

Altogether, 47 Composition I and Reading I students in the study's experimental group, 47 students in the control group, and five Composition I instructors teaching the experimental classes participated, with all teachers having taken the same teaching practicum and also possessing at least three years of Composition I teaching experience. The experimental group enrolled in the linked classes, while the control group took the classes separately. Meanwhile, both sets of teachers possessed the same training and utilized the same assignments, readings, and grading practices. Separately, all students had taken the American College Test and scored adequately in the English-related subjects of reading, critical thinking, and writing considered necessary for entering college. The Academic Success Program, lasting two semesters, provides support to freshmen with deficiencies in reading, writing, speech, or study skills. The director considers the following criteria concerning students' admission: class rank, high-school grade point average, the type of high-school subjects passed, and the level of those courses. These students were selected for the study because of their risk for failing Composition I and Reading I, as well as for not being retained by the university.

\section{FINDINGS}

As overall study findings, experimental group students benefited from taking Composition I linked with Reading I by employing reading-to-write strategies to hone their reading, critical thinking, and writing skills by achieving related Composition I course outcomes at a satisfactory or better level. Indeed, in multiple ways, students' writing practices improved as a consequence of their becoming better readers. Additionally, experimental students demonstrated gains in their reading, critical thinking, and writing abilities as measured by their Composition I's literature review paper. Opposingly, control group students indicated making fewer changes in their reading, critical thinking, and writing habits and produced fewer results demonstrating that they applied reading-to-write practices in order to raise their associated levels in these areas. Furthermore, neither did the control group fare as well in composing the literature review as did the experimental group.

\section{Reading and Critical Thinking Outcomes}

Reading-to-write objectives that experimental group students addressed satisfactorily or better connected to Composition I outcomes included reading; summarizing; taking notes; and critiquing sources from various genres with diverse rhetorical aims and styles; reacting personally to these texts and discussing them; thinking critically; and reading 
one's work for the processes of drafting, revising, and editing. Indeed, both the experimental group and its teachers believed that the former's reading and critical thinking skills profited from the students' focus on reading-to-write theories and dual reading and writing course participation. Notably, $71 \%$ of experimental Composition I students $(n=33)$ or almost three-fourths surveyed at the semester's end identified that their involvement in the joint courses increased their "ability to read and critically think" about Composition I's texts. Similarly, $64 \%$ of the experimental students $(n=30)$ agreed that covering the same readings in both courses proved "beneficial to [their] understanding." Following that, 75\% $(n=35)$ believed that the linked courses assisted them in summarizing and annotating texts, as well as discussing them; $80 \%(n=38)$ felt that the study design promoted their critiquing of sources and reacting personally to readings; and 85\% $(n=40)$ perceived that the connected classes bolstered their practices of reading their work for the processes of drafting, revising, and editing.

Overall, the reading-to-write strategies that experimental students employed in the linked classes allowed them to read and think critically in order to plan their papers in more thoughtful and expert ways. Indeed, by the end, at least $29 \%(n=14)$ or almost a third of students surveyed reported using greater reading and critical thinking patterns in all of the following manners in planning and beginning a paper: reading and rereading texts; summarizing and annotating sources; critiquing sources from various genres with diverse rhetorical aims and styles; reacting personally to these texts and discussing them; thinking critically; and reading their work for the processes of drafting, revising, and editing. Thus, focusing on the reading-to-write methodologies and being enrolled in the joined reading course may have helped the students in understanding the value of employing diverse reading-to-write structures in planning a paper. Comparably, the composition instructors also reported positive outcomes to the merger of Composition I and Reading I. Corroborating the students' view, all composition teachers $(n=5)$ surveyed agreed that covering the reader's texts in both the classes and utilizing similar daily assignment topics connected to those same readings improved students' "reading" and "critical thinking" skills in the ways that the students had reported previously.

Separately, the Reading director identified the joining of Composition I and Reading I as valuable, too. According to the director's report, of experimental students surveyed at the reading course's end, $80 \%(n=38)$ indicated that Reading I supported their addressing of Composition I's reading, critical thinking, and writing outcomes. Furthermore, $71 \%(n=33)$ identified the value in the two courses being tied together and also believed that the classes had been constructed successfully upon each other in order to focus upon reading-to-write strategies. Additionally, according to the report, by the semester's end, the experimental students enrolled in the connected classes demonstrated a $90 \%$ greater degree of awareness of reading strategies and were more likely to implement them in approaching a text than before as per the results of the Metacognitive Reading Strategies Inventory (Mokharti \& Reichard, 2002) and Reading Inventory for the Classroom (Flynnt \& Cooter, 2004). Separately, compared with the control group, the experimental reading students gained a $30 \%$ greater awareness in the reading inventoried areas than did their peers. Arguably, the study, which increased many experimental students' reading and critical thinking skills, assisted the students not 
only in meeting Composition I's writing goals but also in addressing their reading course's objectives as part of a focus on reading-to-write structures.

\section{Writing and Revising Outcomes}

Reading-to-write objectives that experimental students addressed satisfactorily or better adhering to Composition I outcomes included composing work with specified purposes that contextualized what one has read, prewriting and outlining, writing multiple drafts, revising, editing one's work, and seeking assistance. Notably, both the experimental students enrolled in the linked classes and their teachers believed that the former's writing skills profited from the students' attention to reading-to-write premises and dual course participation. Besides acknowledging the merit of offering the conjoined composition and reading courses to promote students' greater reading and critical thinking practices, the students and teachers in the experimental classes also agreed that the study design had assisted the experimental students in becoming better writers as they applied reading-to-write methodologies. Of the experimental students, $67 \%(n=$ 31 ), or more than two-thirds, surveyed at the end concurred that being placed in the paired classes led to their greater "ability to write about" Composition I's course topics. Indeed, the students believed that by Composition I's close, they could orchestrate their papers in more thoughtful and expert ways than previously. Specifically, at least 29\% ( $n$ = 14) or almost a third of experimental students surveyed reported their greater employment of all of the following writing practices meant to assist one in tackling a paper: knowing how to compose work with specified purposes contextualizing what one read, prewriting and outlining, writing multiple drafts, revising extensively, editing one's work, and seeking assistance. Additionally, all teachers $(n=5)$ surveyed agreed that the experimental composition course's model of providing class discussions, daily assignments, and essays enabled students to become "better writers."

In the post-survey, experimental students provided additional feedback about the improved reading-to-write strategies they were utilizing. As the first process in which experimental students strengthened their writing, $29 \%(n=14)$ reported their embarking upon more prewriting strategies in beginning a paper than before, including utilizing outlining or listing practices and expanding the amount of time spent on writing a draft. As the second outcome involving the experimental students' composition processes, by the finish, $42 \%(n=20)$ agreed that they generally wrote more than one draft of an essay before submitting the final paper now. Notably, this change in students' purported willingness to rework and reengage a particular essay represents a positive trend, as in Composition I, all students submit three versions of a paper (a rough draft, a working draft, and a final draft) for review. Specifically, as steps experimental students employed in composing, revising, and editing their drafts, in their post-survey and reflective essay comments, some explained that they had learned to review the essay prompt, concentrate on setting down their ideas, expand their initial thoughts, and correct their grammatical and mechanical errors in a more comprehensive manner. Third, by the semester's close, as another result, at least $51 \%$ of experimental students $(n=24)$ surveyed made more extensive changes upon revising their papers, conducted more editing, and solicited more assistance than before in each area. Indeed, of the composition-related strategies 
detailed in this findings section for writing and revising outcomes, the mode of change in which the experimental students surveyed reported undergoing the biggest adjustments were that of revision and soliciting support.

Overall, based on experimental students' surveys and commentary, many adopted reading-to-write habits and adjusted their composing habits beneficially after taking Composition I and Reading I together. Nonetheless, the students transformed their practices and papers to varying degrees and for diverse purposes. Indeed, according to the experimental students' post-survey and reflective essay comments, only one recorded rendering changes to his reading-to-write composition strategies in all four necessary categories: planning, drafting, revising, and seeking assistance. Still, of the 47 experimental participants, $57 \%(n=27)$ or over half of those providing such commentary on the post-survey or reflective essay identified having conducted some valuable alteration to their writing patterns. Indeed, in this high-needs, experimental student population, nearly three out of five reported utilizing at least one new reading, critical thinking, or writing strategy to assist them, including reading; summarizing; taking notes; and critiquing sources from various genres with diverse rhetorical aims and styles; reacting personally to these texts and discussing them; thinking critically; and reading one's work for the processes of drafting, revising, and editing. Comparably, of the control group students who commented similarly in the post-survey and reflective essay about adopting reading-to-write strategies and shifting their composing habits after taking Composition I, a contrast between the two groups can also be seen. Notably, the control group students had provided similar comments about adjusting their reading, critical thinking, and writing processes according to the same categories of changes rendered as did the experimental students. However, according to the commentary from those in the control group, only $40 \%(n=19)$ indicated making any modification in their habits. Thus, according to the data that both groups provided, the experimental course design helped more students to improve their reading, critical thinking, and writing processes and to a higher degree than did the control group model.

\section{Assessing the Literature Review Paper}

As a means of evaluating students' greater writing achievements, raters read Composition I students' literature review paper and assessed both groups' outcomes for the essay, a genre that encourages reading-to-write and critical thinking as integral acts to be performed in engaging a literature review. Indeed, the essay involves the analysis, synthesis, and evaluation of sources; the requirement for one's personal input; the need for organization, development, and clarity; the correct use of diction, style, and voice; and the meeting of audience and genre requirements. Upon assessing the papers, the raters determined that the experimental students performed highest in the categories of organization, development and clarity, and audience and genre requirements, all areas strongly predicated upon good reading-to-write practices. Additionally, $80 \%(n=38)$ of these students met all of the literature review's objectives. Notably, these findings are important in that they suggest that offering the linked composition and reading courses, as well as implementing reading-to-write practices in Composition I, assisted the experimental students greatly in not only addressing their most important Composition I 
writing assignment but also in completing the smaller written ones leading up to it. Likewise, the experimental students would have needed to have employed related critical thinking processes in tackling their research topic for the literature review, as well as utilizing reading practices in evaluating their sources and critiquing their literature review paper drafts. Meanwhile, control group students achieved comparable but lower scores for each literature review rubric category, with students' implementation of organization, and development and clarity rating as the highest areas of accomplishment similarly. Specifically, compared to the experimental students, $65 \%$ of the control group $(n=31)$ met all of the literature review's criteria. Hence, in the bigger picture, the experimental classes, with their emphasis on reading-to-write strategies, arguably elevated more students' reading, critical thinking, and writing outcomes according to the measure of the literature review, with the experimental students having a $15 \%$ higher rate of achieving the essay's outcomes than did the control group. (See Table 1 for student outcomes related to the literature review paper).

Table 1

Writing Categories for Assessing Students' Literature Review Paper, with "1" Being the Lowest and "5" Being the Highest Per Each Student Paper

\begin{tabular}{|c|c|c|c|c|c|}
\hline & $\begin{array}{c}\text { Insufficient } \\
\text { (1) }\end{array}$ & $\begin{array}{l}\text { Fair } \\
\text { (2) }\end{array}$ & $\begin{array}{l}\text { Sufficient } \\
\text { (3) }\end{array}$ & $\begin{array}{c}\text { Good } \\
\text { (4) }\end{array}$ & $\begin{array}{c}\text { Excellent } \\
\text { (5) }\end{array}$ \\
\hline \multicolumn{6}{|l|}{ Organization } \\
\hline \multirow[t]{2}{*}{ Experimental Group } & $5 \%$ & $5 \%$ & $50 \%$ & $20 \%$ & $20 \%$ \\
\hline & $n=2$ & $n=2$ & $n=24$ & $n=9$ & $n=9$ \\
\hline \multirow[t]{2}{*}{ Control Group } & $15 \%$ & $15 \%$ & $50 \%$ & $20 \%$ & $0 \%$ \\
\hline & $n=7$ & $n=7$ & $n=24$ & $n=9$ & $n=0$ \\
\hline \multicolumn{6}{|l|}{ Development and Clarity } \\
\hline \multirow[t]{2}{*}{ Experimental Group } & $5 \%$ & $5 \%$ & $40 \%$ & $20 \%$ & $30 \%$ \\
\hline & $n=2$ & $n=2$ & $n=19$ & $n=9$ & $n=14$ \\
\hline \multirow[t]{2}{*}{ Control Group } & $10 \%$ & $20 \%$ & $40 \%$ & $30 \%$ & $0 \%$ \\
\hline & $n=5$ & $n=9$ & $n=19$ & $n=14$ & $n=0$ \\
\hline \multicolumn{6}{|l|}{ Diction, Style, and Voice } \\
\hline \multirow{2}{*}{ Experimental Group } & $10 \%$ & $10 \%$ & $40 \%$ & $25 \%$ & $15 \%$ \\
\hline & $n=5$ & $n=5$ & $n=19$ & $n=12$ & $n=7$ \\
\hline \multirow{2}{*}{ Control Group } & $10 \%$ & $20 \%$ & $40 \%$ & $25 \%$ & $5 \%$ \\
\hline & $n=5$ & $n=5$ & $n=19$ & $n=12$ & $n=2$ \\
\hline \multicolumn{6}{|l|}{ Audience and Genre } \\
\hline \multirow[t]{2}{*}{ Experimental Group } & $15 \%$ & $10 \%$ & $40 \%$ & $25 \%$ & $10 \%$ \\
\hline & $n=7$ & $n=4$ & $n=19$ & $n=12$ & $n=5$ \\
\hline \multirow{2}{*}{ Control Group } & $15 \%$ & $20 \%$ & $40 \%$ & $25 \%$ & $0 \%$ \\
\hline & $n=7$ & $n=5$ & $n=19$ & $n=12$ & $n=0$ \\
\hline
\end{tabular}

$N=94$ students

\section{DISCUSSION}

Overall, this study portrays a recent view of the value of implementing reading-to-write processes and connecting reading and writing practices by linking reading and writing classes. The study's findings substantiate and further researchers' claims regarding the benefits of employing reading-to-write practices for students and offering conjoined reading and composition courses, as well as pointing to their valuable effects upon students' reading, critical thinking, and writing outcomes. Moreover, the study 
contributes to the field by providing new knowledge of the literature review assignment and its assessed reading-to-write outcomes upon at-risk students at a comprehensiveresearch university. Indeed, the experimental students' satisfactory or better achievement of all literature review outcomes was $80 \%$, a rate $15 \%$ higher than that of the control group. Likewise, because the literature review is the most difficult essay that Composition I students must master, their ability to engage competently with it indicated their ability to tackle the larger curriculum more generally. Besides that, the study demonstrates that students can achieve Composition I related reading, critical thinking, and writing goals with the addition of only one extra hour per week through their enrolment in a connected, one-credit reading course. Lastly, the study is significant because it shows that reading and writing teachers can collaborate successfully and that a paired course curriculum can be orchestrated with aligned reading assignments that both sets of teachers feel confident in utilizing.

Summarily, an initiative, linking Composition I and Reading I, to promote a range of reading-to-write strategies proved valuable in its ability to address a group of at-risk students' reading, critical thinking, and writing outcomes in Composition I. Comparably, the study's findings are noteworthy because previous studies did not reveal how many students improved their compositional practices and to what degree (see $\mathrm{Yu}, 2016$ ), the specific writing gains from which students benefited (see Lockhart \& Soliday, 2016), or the manner in which the reading and writing classes offered were connected and the detailed reading-to-write practices that students utilized for the design (see Goen \& Gillotte-Tropp, 2003). Moreover, the previous studies lacked rigor in that two did not feature a specified control group, and none included a large number of student participants or employed a mixed method in order to benefit from the largest number and type of instruments available.

\section{Reading and Critical Thinking Outcomes}

Reading-to-write objectives that experimental students addressed satisfactorily or better related to Composition I outcomes included reading; summarizing; annotating; critiquing sources from various genres with diverse rhetorical aims and styles; reacting to these texts and discussing them; thinking critically; and reading their work for the processes of drafting, revising, and editing (see Gruenbaum, 2012; Horning \& Kramer, 2013; Howard, Rodrigue, \& Serviss, 2010; Skomski, 2013). Consequently, the study' experimental students benefited from implementing reading-to-write objectives in the same manner as had those in the literature (see Flower, Stein, Ackerman, Kantz, McCormick, \& Peck, 1990; Helmers, 2003). Indeed, the experimental students offering commentary on the post-survey and reflective essay believed that the linked classes provided them with a greater sense of course cohesion and purpose, as well as more confidence in their reading, critical thinking, and writing abilities (see Zawacki \& Williams, 2001). Furthermore, the experimental students perceived that their reading and writing teachers worked together more fully to identify and assist them in their individual needs than had been the case in previous related courses (see Luebke, 2002).

In this light, the study proved valuable in demonstrating to the large degree to which students' reading-to-write outcomes could affect their reading, critical thinking, and 
writing practices and processes, especially when students saw these acts and aspects as being promoted in both classes. Notably, reading prefigures and affects students' writing outcomes (Conley, 2005), and reading sources before one begins writing is a vital step of the composition process (Sharp, 2016). Likewise, when one encounters new or difficult genres with different and unfamiliar audience expectations, structures, and styles, such as was the emphasis of Composition I, where students read personal essays, case studies, articles, and other matter, one should employ additional reading-to-write strategies (see Zubaidah, Corebima, Mahanal, \& Mistianah, 2018). However, by concentrating on reading-to-write practices in both Reading I and Composition I, the experimental students gained the extra time necessary to engage with and discuss their readings before beginning their writing assignments (see Zawacki \& Williams, 2001). Indeed, having an extended time with the readings allowed the experimental students to garner a greater success with them than did those in the control group. When students understand their course readings and can explore them with accuracy in their writing assignments, they are more inspired to engage in both activities and also can work at a greater level (Bunn, 2013), and the experimental students proved able to accomplish both of these tasks satisfactory via their engaging in reading-to-write acts involving reading, critical thinking, and writing for the composition class (see Nowacek, 2011).

\section{Writing and Revising Outcomes and Assessing the Literature Review Paper}

Reading-to-write objectives that experimental students addressed satisfactorily or better related to Composition I outcomes included composing work with specified purposes contextualizing what one has read, prewriting and outlining, writing multiple drafts, revising extensively, editing one's work, and seeking assistance. Hence, for the study, experimental students benefited from employing reading-to-write objectives in the same manner as had those in the literature (Flower, Stein, Ackerman, Kantz, McCormick, \& Peck, 1990; Yu, 2016). As the study proved, composition instructors can teach reading, as well as writing competencies, in order to assist students with various reading-to-write outcomes. First, in their writing classes, teachers can join reading and writing practices in order to aid students in not only reacting narrowly and personally to texts (Helmers, 2003) but also in viewing reading as a dialogue between readers and writers. Being able to engage with an author's text instead of simply reacting personally to a subject is arduous for many students, and, in the study, addressing this scenario remained a main concern for the experimental composition classes' teachers. Yet because the study offered extra time for experimental students to interact with their course readings, they were able not only to respond to them personally but also deconstruct and decode them, such as through composing the literature review. Second, as reading-to-write practices, faculty can teach analysis, synthesis, and source evaluation processes, so that students can address complex ideas and configure them to render a larger picture (Gruenbaum, 2012), and, for the study, assigning students the literature review was a task that allowed them to tackle these competencies. However, third, reading-to-write models can also aid students in composing work with other specified purposes that contextualizes what one has read, including arguments, narratives, and reflections (Howard, Rodrigue, \& Serviss, 2010), and, in the study, being able to read well assisted the experimental students in 
completing the literacy narrative, advertisement analysis, rhetorical analysis, and reflective essay, too.

As a means of evaluating students' writing-related, Composition I achievements, raters read their literature review paper and assessed their outcomes for the essay, a genre that encourages reading-to-write and critical thinking as integral acts to be performed in conducting a literature review, a genre involving the analysis, synthesis, and evaluation of sources; the requirement for one's personal input; the need for organization, development, and clarity; the correct use of diction, style, and voice; and the meeting of audience and genre requirements. Upon assessing the papers, the raters determined that the experimental students performed highest in the categories of organization, development and clarity, and audience and genre requirements, all areas predicated upon good reading-to-write practices. Nevertheless, $80 \%(n=38)$ of experimental students also met all of the literature review's objectives, indicating that, foreseeably, they would have performed well in other reading, critical thinking, and writing course tasks for Composition I, too. Notably, to gather information and write about it, students must be able to read competently (Rosyida \& Ghufron, 2018), and for the study, the experimental course model assisted students in this capacity, especially in their completing of the literature review. Likewise, to be able to convey one's ideas sufficiently, one must be able to utilize a diverse vocabulary (Skomski, 2013), but through the study, the joined classes aided students in achieving the leisure necessary to explore their word usage because of the extra time available. Largely, how readers select, analyze, and understand texts is affected by the choices that writers make about a text's goals, genre, style, and audience (Zubaidah, Corebima, Mahanal, \& Mistianah, 2018), yet by utilizing distinct reading-to-write practices, especially in tackling the literature review, the most difficult demand for the course.

\section{RECOMMENDATIONS, LIMITATIONS, AND CONCLUSION}

As part of most FYC classes' requirements, students must demonstrate their rhetorical consciousness in reading, critical thinking, and writing acts (Helmers, 2003), even if substantial growth in their writing skills can only be measured slowly and over cumulative semesters (Hembrough, 2019). One strategy for assisting students in developing their composition processes is to implement reading-to-write methodologies and to offer students linked first-year reading and writing courses. Indeed, the study's conjoined Composition I and Reading I classes assisted experimental students in navigating the former course's reading, critical thinking, and writing outcomes in a satisfactory or better manner by providing them with various reading-to-write concepts, including reading, annotating, summarizing, and critiquing sources from various genres with diverse rhetorical aims and styles; reacting personally to these texts and discussing them; planning and composing work with specified purposes contextualizing what one has read; and reading one's work for the processes of drafting, revising, and editing. Additionally, according raters' assessment of the literature review, the connected Composition I and Reading I courses aided the experimental students in fulfilling writing course objectives associated with organization; development and clarity; audience and genre requirements; and diction, style, and voice requirements to a 
satisfactory or higher degree. This latter finding is significant as the literature review is Composition I's most complex essay, requiring extensive reading-to-write strategies. Concerning each finding, students in the linked classes performed better than those in the control group. Consequently, one can conclude also that the study course model provided students with a valuable learning environment promoting a reading-to-write design assisting them in addressing reading, critical thinking, and writing outcomes that would benefit them in future college classes, as well as the work world.

Proceeding, this paper will document the study's limitations and requisite for future research. As the largest limitation, the number of students included was somewhat small if still statistically significant, and a larger sample taken from multiple years might be obtained in future studies. Furthermore, in further work, it is important to ascertain whether not only at-risk students but also all students enrolling in FYC would benefit from linked reading and writing classes, even if it meant taking an extra one-credit course. Similarly, in the current study, it would have been valuable if raters could have evaluated all of students' Composition I essays, including the literacy narrative, advertisement analysis, rhetorical analysis, in-class essay, and reflective essay, instead of only the literature review, in order to measure students' use of organization; development and clarification of ideas; diction, style, and voice; and audience and genre features, all of which the conjoined courses' reading-to-write strategies could affect in like regard.

Lastly, this article will present a few recommendations for writing faculty and administrators seeking to employ greater reading-to-write practices in their classrooms or to pair Composition I and Reading I courses at their own institutions. First, writing instructors should have additional discussions about and even training as necessary in teaching reading-to-write strategies as a part of their curriculum. To facilitate this practice, administrators themselves should become more informed about the reading-towrite model and the motivation to implement reading-to-write strategies. For instance, administrators could offer a workshop or seminar related to the model at their institution in order to make it more understood. Additionally, instructors, on their end, should ensure that they demonstrate to students how to employ unique or further reading-towrite strategies whenever students encounter new or difficult genres with different audience expectations, structures, and styles that are unfamiliar. As a recommendation for those proposing to connect a set of reading and composition classes, writing teachers also should be encouraged to communicate with reading faculty beforehand as to the shared goals they may possess for their classes. Then, if faculty decide to link their courses, they should endeavor to create clear curricula, schedules, and outcomes for both classes to address, including overlapping goals and weekly lesson plans for all instructors to follow. Lastly, writing instructors and administrators might also consider the value of pairing a reading class with a second-semester or second-year writing class in order to provide students with the extra time for discussing and studying the readings that students will be engaging in that writing course, too.

As this study confirms, rethinking the curricular scenarios involved in connecting reading and writing classes, as well as asking composition instructors to teach reading- 
to-write tactics in new ways, are difficult. At the composition course level, large changes may be necessary in re-envisioning one's class design, and thus teachers and students may need to adjust their beliefs and attitudes about the content featured in a writing class (Adler-Kassner \& Estrem, 2007). Nonetheless, as this study suggests, through such curricular shifts, Composition I students might achieve greater reading-to-write skills and higher writing and literacy levels, as they learn to read actively and reflectively, engaging with a range of textual types that they will encounter in college and beyond (Carillo, 2015). Teachers who understand the complicated and intertwined nature of reading and writing processes tend to be more sympathetic and willing to teach students these linked skills than those who believe students should have mastered the discipline of reading before beginning college (Colombo \& Prior, 2016). Indeed, in the end, faculty willing to rethink their approaches to teaching reading and writing and to acknowledge how these topics and techniques are related on a higher level can assist students with their reading-to-write practices, a design that will lead to students' better preparation for reading, critical thinking, and writing acts more generally.

\section{REFERENCES}

Adler-Kassner, L., \& Estrem, H. (2007). Reading practices in the writing classroom. Writing Program Administrators, 31(1/2), 35-47.

Allen, E., \& Seaman, C. (2007). Likert scales and data analyses. Quality Progress, 40, 64-65.

Belet Boyaci, S., \& Güner, M. (2018). The impact of authentic material use on development of the reading comprehension, writing skills and motivation in language course 1. International Journal of Instruction, 11(2), 351-368.

Bernard, H. R., \& Bernard, H. R. (2012). Social research methods: Qualitative and quantitative approaches. Los Angeles, CA: Sage.

Boyce, C., \& Neale, P. (2006) Conducting in-depth interview: A guide for designing and conducting in-depth interviews for evaluation input. Pathfinder International Tool Series, Monitoring and Evaluation-2.

Bunn, M. (2013). Motivation and connection: Teaching reading (and writing) in the composition classroom. College Composition and Communication, 64(3), 496-516.

Carillo, E. (2015). Securing a place for reading in composition: The importance of teaching for transfer. Logan, Utah: Utah State UP.

Colombo, L., \& Prior, M. (2016) How do faculty conceptions on reading, writing and their role in the teaching of academic literacies influence their inclusive attitude? Illha do Desterro, 69(3), 115-124.

Conley, D. (2005). College knowledge: What it really takes for students to succeed and what we can do to get them ready. San Francisco, CA: Jossey-Bass.

Cresswell, J., \& Creswell, D. (2017). Research design: Qualitative, quantitative, and mixed methods approaches. $5^{\text {th }}$ ed. Los Angeles, CA: Sage. 
Cumming, A., Lai, C., \& Cho, H. (2016). Students' writing from sources for academic purposes: A synthesis of recent research. Journal of English for Academic Purposes, 23, 47-58. doi: 10.1016/j.jeap.2016.06.002.

Flower, L., Stein, V., Ackerman, J., Kantz, M., McCormick, K., \& Peck, W. (1990). Reading-to-write: Exploring a cognitive and social process. New York: Oxford U.

Flynt, E., \& Cooter, R. (2004). Reading inventory for the classroom. Scottsdale, AZ: Gorsuch.

Goen, S., \& Gillotte-Tropp, H. (2003). Integrating reading and writing: A response to the basic writing "crisis." Journal of Basic Writing, 22(2), 90-113.

Grabe, W., \& Zhang, C. (2013). Second language reading-writing relations. In A. Horning, \& E. Kraemer (Eds.). Reconnecting reading and writing (pp. 108-133). Anderson, SC: Parlor.

Gruenbaum, E. (2012). Common literacy struggles with college students: Using the reciprocal teaching technique. J. of College Reading and Learning, 42(2), 110-116.

Haswell, R. (1991). Gaining ground in college writing: Tales of development and interpretation. Dallas, TX: Southern Methodist UP.

Hayes, S., \& Williams, J. (2016). ACLT 052: Academic literacy-An integrated, accelerated model for developmental reading and writing. NADE Digest, 9(1), 13-21.

Helmers, M. (2003). Introduction: Representing reading. In M. Helmers (Ed.), Intertexts: Reading pedagogy in college writing classrooms (pp. 3-26). Mahwah, NJ: Lawrence Erlbaum.

Hembrough, T. (2019). A case study: Focusing on sustainability themes and ecocomposition through student blogs in a professional and technical writing course. International Journal of Instruction, 12(1), 895-914.

Hern, K., \& Snell, M. (2013). High challenge, high support classrooms for underprepared students. Oakland, CA: Learning Works.

Horning, A. (2013). Writing and reading across the curriculum: Best practices and practical guidelines. In A. Horning, \& E. Kraemer (Eds.). Reconnecting reading and writing (pp. 74-88). Anderson, SC: Parlor P.

Hung, B., \& Van, L. (2018). Depicting and outlining as pre-writing strategies: Experimental results and learners' opinions. International Journal of Instruction, 11(2), 451-464. doi: 10.12973/iji.2018.11231a.

Irwansyah, D., Nurgiyantoro, B., \& Sugirin. (2019). A literature-based reading instructional model for Islam-Affiliated University in Indonesia. International Journal of Instruction, 12(3), 577-594. doi: 10.29333/iji.2019.12335a. 
Javadi, J., \& Mohammadi, M. (2019). The effect of critical discourse-based instruction on Iranian English major students' reading comprehension. International Journal of Instruction, 12(1), 33-52. doi: 10.29333/iji.2019.1213a.

Javed, M., Siew, L., \& Mohamed, A. (2015). Developing reading comprehension modules to facilitate reading comprehension among Malaysian secondary school ESL students. International Journal of Instruction, 8(2), 139-154.

Jawas, U. (2019). Writing anxiety among Indonesian EFL students: Factors and strategies. International Journal of Instruction, 12(4), 733-746. doi: 10.29333/iji.2019.12447a.

Kalamkarian, H., Raufman, J., \& Edgecombe, N. (2015). Statewide developmental education reform: Early implementation in Virginia and North Carolina. New York City, NY: Community College Research Center.

Lockhart, T., \& Soliday, M. (2016). The critical place of reading in writing transfer (and beyond): A report of student experiences. Pedagogy, 16(1), 23-37.

Luebke, S. (2002). Using linked courses in the general education curriculum. Academic Writing. Retrieved from https://wac.colostate.edu/aw/ articles/luebke2002.htm.

Marsh, B. (2015). Reading-writing integration in developmental and first-year composition. Teaching English in the Two-Year College, 43(1), 58-70.

Merriam, S. (1998). Qualitative research and case study applications in education. New York City, NY: Jossey-Bass.

Mutnick, D., \& Lamos, S. (2014). Basic writing pedagogy: Shifting academic margins in hard times. In G. Tate (Ed.) A guide to composition pedagogies (pp.20-36).. New York, NY: Oxford U.

Mokhtari, K., \& Reichard, C. (2002). Assessing students' metacognitive awareness of reading strategies. Journal of Educational Psychology, 94(2), 249-259. doi: 10.1037//0022-0663.94.2.249.

Morse, J. M., \& Niehaus, L. (2009). Mixed methods design: Principles and procedures. Walnut Creek, CA: Left Coast P.

Nowacek, R. (2011). Agents of integration: Understanding transfer as a rhetorical act. Carbondale, IL: Southern IL UP.

Pacello, J. (2014). Integrating metacognition into a developmental reading and writing course to promote skill transfer. Journal of College Reading and Learning, 44(2), 119140. doi: 10.1080/10790195.2014.906240.

Pathan, Z., Ismail, S., \& Soomro, N. (2019). An investigation into receptive vocabulary growth and its predictability for reading development of university students in a semester course. International Journal of Instruction, 12(1), 797-808. doi: 10.29333/iji.2019.12151a. 
Rosyida, F., \& Ghufron, M. (2018). Herringbone and tri focus Steve Snyder technique: The techniques for teaching reading comprehension viewed from students' reading habit. International J. of Instruction, 11(3), 603-616. doi: 10.12973/iji.2018.11341a.

Sharp, L. (2016). Acts of writing: A compilation of six models that define the processes of writing. International Journal of Instruction, 9(2), 77-90.

Schutt, R. (2014). Investigating the social world: The process and practice of research. $8^{\text {th }}$ ed. Los Angeles, CA: Sage.

Skomski, K. (2013). First year writing: Forward movement, backward progress. In A. Horning, \& E. Kraemer (Eds.). Reconnecting reading and writing (pp. 89-107). Anderson, SC: Parlor.

Strauss, A. (1987). Qualitative analysis for social scientists. Cambridge, England: Cambridge UP.

Thiede, K., Griffin, T., Wiley, J., \& Anderson, M. (2010). Poor meta comprehension accuracy as a result of inappropriate cue use. Discourse Processes, 47(4), 331-362.

Yang, Y. (2010). Developing a reciprocal teaching/learning system for college remedial reading instruction. Computers \& Education, 55, 1193-1201.

$\mathrm{Yu}$, H. (2016). Perceptions about reading to write and its practices in a L2 writing course. Advanced Science and Technology Letters, 127, 80-84.

Zawacki, T., \& Williams, A. (2001). Is it still WAC? Writing within interdisciplinary learning communities. In S. McLeod et al. (Eds.). WAC for the new millennium (pp. 109-140). Urbana, IL: NCTE.

Zubaidah, S., Corebima, A., Mahanal, S., \& Mistianah. (2018). Revealing the relationship between reading interest and critical thinking skills through remap GI and remap jigsaw. Int. Journal of Instruction, 11(2), 41-56. doi: 10.12973/iji.2018.1124a.

\section{Appendix: End-of-the-Semester Interview Questions for Composition I Instructors}

1) Do you feel as if the readings your students have completed helped them become better readers? Better writers?

2) Do you feel as if the class discussions in which your students have participated helped them become better readers? Better writers?

3) Do you feel as if the essays your students submitted have helped them become better readers? Better writers?

4) Do you feel as if the smaller writing assignments your students have completed helped them become better readers? Better writers?

5) Do you feel as though covering the same course readings in both Composition I and Reading 1 benefitted your students' reading skills? Writing skills?

6) Can you explain any benefits, drawbacks, or problems in your teaching Composition I as a linked course with Reading I? 